\title{
ACBD6 wt Allele
}

National Cancer Institute

\section{Source}

National Cancer Institute. ACBD6 wt Allele. NCI Thesaurus. Code C114701.

Human ACBD6 wild-type allele is located in the vicinity of $1 \mathrm{q} 25.1$ and is approximately 228

$\mathrm{kb}$ in length. This allele, which encodes acyl-CoA-binding domain-containing protein 6 , is involved in binding to acylated coenzyme A. 